\title{
Development of an In-situ Analyzer for Nutrient Monitoring in Seawater
}

\author{
Hongliang Wang ${ }^{1,2,}$, Shuwei Zhang ${ }^{2}$, Cuilian Guo ${ }^{2}$, and Dongzhi Chu \\ ${ }^{1}$ National Deep Sea Center, State Oceanic Administration, Qingdao 266237, China \\ ${ }^{2}$ Shandong Provincial Key Laboratory of Ocean Environment Monitoring Technology, Shandong \\ Academy of Sciences Institute, Qingdao 266001, China
}

awhl@ndsc.org.cn

Keywords: Nutrient; In-situ; Analyzer; Seawater

Abstract. This study presents the development of a compact and portable in-situ analyzer for nutrient determination. The analyzer can detect the seawater concentrations of nitrate, nitrite, phosphate, ammonia and silicate based on spectrometric method and flow injection analysis with the use of peristaltic pump, 3-port solenoid valves and flow cells. Detection limits are, respectively, $0.3,0.1,0.1$, 0.3 and $0.2 \mu \mathrm{M}$ for nitrate, nitrite, phosphate, ammonia and silicate. With the use of wash solution and standards, the analyzer can work for long time during seawater monitoring.

\section{Introduction}

In both process studies and routine monitoring, in situ chemical measurement capabilities offer a variety of substantial advantages relative to shipboard and laboratory analysis[1]. With the use of in situ analyzers, high precision and accuracy of measurements can be achieved, and the spatial and temporal resolution of the acquired data can be increased[2,3].

Using wet chemical techniques with the addition of chemical regents and based on laboratory methods, there has been a rapid development of in-situ analyzers for the determination of nutrient in seawater during the past decades[2-4]. Nutrients react with the added chemical regents, form new chemical compounds with chromogenic groups, thus can be detected using spectrometric method. Coupled with flow analysis techniques, such as flow injection analysis (FIA) and continuous flow analysis (CFA), one or multiple nutrients (nitrate, nitrite, phosphate, ammonia, silicate) can be determined[3-5].

In the present work, we describe a compact, portable, sensitive, and rapid in-situ analyzer for nutrient determination using FIA and spectrometric method. Characteristics, Analytical methods and laboratory measurements of the instrument are described in this paper.

\section{Material and methods}

Analyzer characteristics. The analyzer is a complete, compact, in situ spectrophotometric system, including fluid module, system control and data acquisition module. Fig. 1 shows the 3D model of the analyzer. The entire analysis system is contained in a rigid PVC made housing that is $160 \mathrm{~mm}$ in diameter and $810 \mathrm{~mm}$ long. 


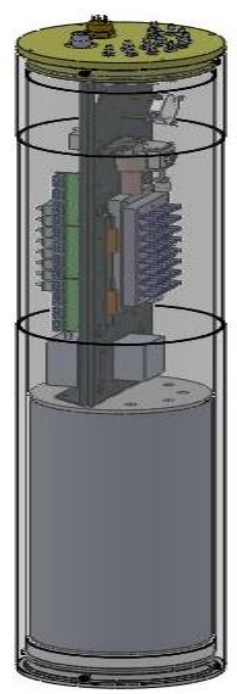

Fig. 1. 3D model of the analyzer.

The schematic diagram of flow and detection manifold is presented in Fig. 2. One peristaltic pump (KCS, Kamoer Fluid co. Itd., China) and fourteen 3-port solenoid valves (SV1 to SV14 in Fig. 2, LVM105 from SMC, Japan) are used for the selective injection of the different fluids: sample, wash solution, DIW, standards, and reagents. The peristaltic tubes and flow tube (PTFE) are $0.80 \mathrm{~mm}$ i.d., and the flow rates are set to about $1.0 \mathrm{~mL} \mathrm{~min}^{-1}$ by adjusting the rotational speed of peristaltic pump.

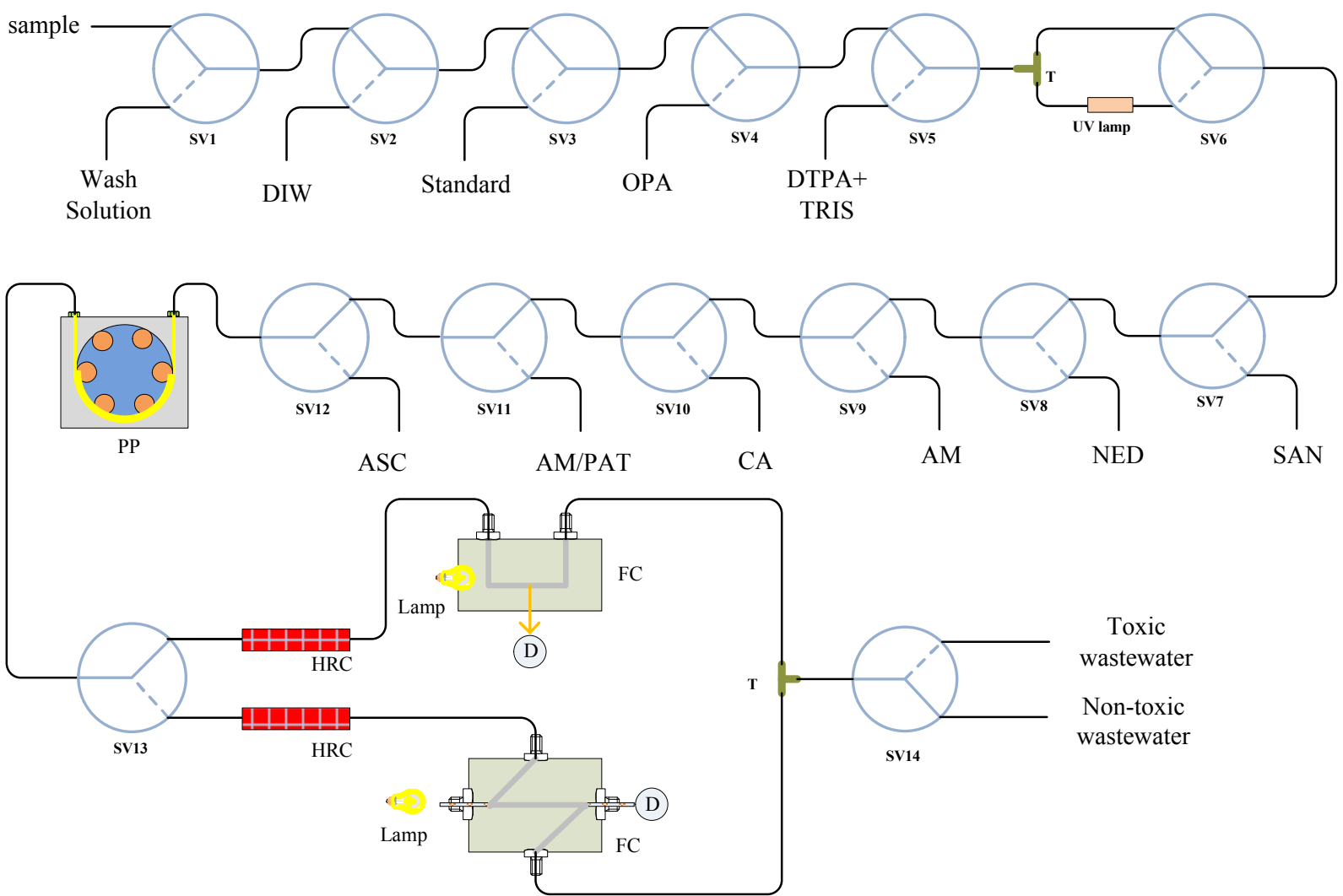

Fig. 2. Schematic diagram of the manifold used for the analysis of nutrient. SV, solenoid valves; PP, peristaltic pump; PP, peristaltic pump; T: tee; HRC, heating reaction coil; D, detector; FC, flow cell. DTPA, Diethylene triamine pentaacetic acid; TRIS, Tris-Hydroxymethylaminomethane; SAA, Sulphanilamide; NED, N-(1-Naphthyl)ethylenediamine; OPA, $o$-Phthalaldehyde; AM, Ammonium molybdate; CA,Citric acid; PAT, Potassium antimonyl tartarate; ASC, Ascorbic acid.

Some manifold tubes between different solenoid valves are replaced by a two-layer engraved circuit in PMMA [poly(methylmethacrylate), $140 \times 80 \times 24 \mathrm{~mm}$, homemade]. The valves are integrated directly into the engraved circuit to limit the use of tubes and minimize the dead volumes. Standards and 
reagents $(100-500 \mathrm{~mL})$ are stored in flexible bags, connected to the engraved manifold with Teflon and PTFE tubing.

Two flow cells are used in analysis. One is the Z-shaped PMMA flow cell ( $L=20 \mathrm{~mm}$, i.d. $=2 \mathrm{~mm}$, homemade), and the other is the quartz fluorescence flow cell $(L=10 \mathrm{~mm}$, i.d. $=2 \mathrm{~mm}$, Jingke optics, China).

The light is emitted by LEDs $(525 \mathrm{~nm}, 810 \mathrm{~nm}$ and $880 \mathrm{~nm})$. LEDs are fixed in a homemade optical coupler with two output light beams. One beam pass through the Z-shaped flow cell and return to the photodiode via plastic optical fibers (i.d. $2 \mathrm{~mm}$ ). The other connect to the photodiode directly via plastic optical fibers (i.d. $2 \mathrm{~mm}$ ). The signal is obtained using synchronous detection. Using the ratio of the light intensities from two photodiodes, the intensity variation due to the change of voltage and environmental temperature can be eliminate.

The analyzer has autonomous and standby mode, and can be programmed and controlled by homemade software. Users can select one or multi analytes for continuous or intermittent monitoring. The electrical consumption of the analyzer is $1.2 \mathrm{~A}(12 \mathrm{~V})$.

Analytical methods. The chemical parameters to be measured are nitrate, nitrite, phosphate, ammonia and silicate. Analytical methods are list in Table 2. Reagents (Table 2) were prepared using analytical grade reagents, ultrapure water (Milli-Q, Millipore), or natural seawater.

Table 1. Analytical methods and regents preparation of the analyzer.

\begin{tabular}{|c|c|c|c|c|}
\hline Analyte & $\begin{array}{l}\text { Analytical } \\
\text { methods }\end{array}$ & $\begin{array}{l}\text { Detedction } \\
\text { wavelength }\end{array}$ & Regents name & Preparation \\
\hline \multirow[t]{3}{*}{ Nitrate } & \multirow{3}{*}{$\begin{array}{l}\text { UV reduction, } \\
\text { Griess reaction } \\
\text { and } \\
\text { spectrophoto- } \\
\text { metry }\end{array}$} & \multirow[t]{3}{*}{$540 \mathrm{~nm}$} & $\begin{array}{l}\text { Diethylene triamine } \\
\text { pentaacetic acid } \\
\text { (DTPA) } \\
\text { Tris-Hydroxymethyla-m } \\
\text { inomethane (TRIS) }\end{array}$ & $\begin{array}{l}\text { DTPA } 47.5 \mathrm{~g} \mathrm{l}^{-1} \\
\text { TRIS } 24 \mathrm{~g} \mathrm{l}^{-1} \\
\text { in } \mathrm{HCl} 0.8 \mathrm{~N}\end{array}$ \\
\hline & & & Sulphanilamide (SAA) & $\begin{array}{l}\text { SAA } 20.0 \mathrm{~g} \mathrm{l}^{-1} \\
\text { in } \mathrm{HCl} 0.9 \mathrm{~N}\end{array}$ \\
\hline & & & $\begin{array}{l}\text { N-(1-Naphthyl)ethylen- } \\
\text { ediamine (NED) }\end{array}$ & NED $3.0 \mathrm{~g} \mathrm{l}^{-1}$ \\
\hline \multirow[b]{2}{*}{ Nitrite } & \multirow{2}{*}{$\begin{array}{l}\text { Griess reaction } \\
\text { and } \\
\text { spectrophoto- } \\
\text { metry }\end{array}$} & \multirow[b]{2}{*}{$540 \mathrm{~nm}$} & Sulphanilamide (SAA) & same to Nitrate \\
\hline & & & $\begin{array}{l}\text { N-(1-Naphthyl)ethylen- } \\
\text { ediamine (NED) }\end{array}$ & same to Nitrate \\
\hline \multirow[t]{2}{*}{ Phosphate } & \multirow[t]{2}{*}{$\begin{array}{l}\text { phosphorus } \\
\text { molybdenum } \\
\text { blue and } \\
\text { spectrophoto- } \\
\text { metry }\end{array}$} & \multirow[t]{2}{*}{$880 \mathrm{~nm}$} & $\begin{array}{l}\text { Ammonium molybdate } \\
\text { (AM) } \\
\text { Potassium antimonyl } \\
\text { tartarate (PAT) }\end{array}$ & $\begin{array}{l}\text { AM } 10.0 \mathrm{~g} \mathrm{l}^{-1} \\
\text { PAT } 0.5 \mathrm{~g} \mathrm{l}^{-1} \\
\text { in } \mathrm{H}_{2} \mathrm{SO}_{4} 1.8 \mathrm{~N}\end{array}$ \\
\hline & & & Ascorbic acid (ASC) & $\mathrm{ASC} 40 \mathrm{~g} \mathrm{l}^{-1}$ \\
\hline \multirow{4}{*}{ Ammonia } & \multirow{4}{*}{$\begin{array}{l}\text { OPA } \\
\text { fluorescence }\end{array}$} & \multirow{4}{*}{$\begin{array}{l}\text { Excitation: } \\
365 \mathrm{~nm} ; \\
\text { Emission: } \\
\text { 400 480nm }\end{array}$} & \multirow{4}{*}{$\begin{array}{l}\text {-Phthalaldehyde (OPA) } \\
\mathrm{Na}_{2} \mathrm{~B}_{4} \mathrm{O}_{7} \\
\mathrm{Na}_{2} \mathrm{SO}_{3}\end{array}$} & $1 \mathrm{~g}$ OPA in $25 \mathrm{ml} \mathrm{EtOH}$ \\
\hline & & & & $5 \mathrm{~g} \mathrm{Na}_{2} \mathrm{~B}_{4} \mathrm{O}_{7}$ in $250 \mathrm{ml}$ DIW \\
\hline & & & & $0.2 \mathrm{~g} \mathrm{Na}_{2} \mathrm{SO}_{3}$ in $25 \mathrm{ml} \mathrm{DIW}$ \\
\hline & & & & Mixing three solutions \\
\hline \multirow{3}{*}{ Silicate } & \multirow{3}{*}{$\begin{array}{l}\text { silico-molybde } \\
\text { num blue and } \\
\text { spectrophoto- } \\
\text { metry }\end{array}$} & \multirow{3}{*}{$810 \mathrm{~nm}$} & $\begin{array}{l}\text { Ammonium molybdate } \\
\text { (AM) }\end{array}$ & $\begin{array}{l}\text { AM } 60.0 \mathrm{~g} \mathrm{l}^{-1} \\
\text { in } \mathrm{H}_{2} \mathrm{SO}_{4} 0.7 \mathrm{~N}\end{array}$ \\
\hline & & & $\begin{array}{l}\text { Citric acid (CA) } \\
\text { Potassium antimonyl } \\
\text { tartarate (PAT) }\end{array}$ & $\begin{array}{l}\text { CA } 210 \mathrm{~g} \mathrm{l}^{-1} \\
\text { PAT } 1.6 \mathrm{~g} \mathrm{l}^{-1}\end{array}$ \\
\hline & & & Ascorbic acid (ASC) & ASC $40 \mathrm{~g} \mathrm{l}^{-1}$ \\
\hline
\end{tabular}


Laboratory tests. Analytical performance of the analyzer was tested in laboratory, and the results can be seen in table 2. Detection limits are, respectively, $0.3,0.1,0.1,0.3$ and $0.2 \mu \mathrm{M}$ for nitrate, nitrite, phosphate, ammonia and silicate.

Table 2. Analytical performance of the analyzer in laboratory

\begin{tabular}{|c|c|c|c|}
\hline Analyte & Linearity range & Limit of detection & Time per detection \\
\hline Nitrate & $0.5 \sim 40 \mu \mathrm{M}$ & $0.3 \mu \mathrm{M}$ & 6 \\
\hline Nitrite & $0.2 \sim 20 \mu \mathrm{M}$ & $0.1 \mu \mathrm{M}$ & 3 \\
\hline Phosphate & $0.2 \sim 20 \mu \mathrm{M}$ & $0.1 \mu \mathrm{M}$ & 4 \\
\hline Ammonia & $0.5 \sim 40 \mu \mathrm{M}$ & $0.3 \mu \mathrm{M}$ & 12 \\
\hline Silicate & $0.4 \sim 40 \mu \mathrm{M}$ & $0.2 \mu \mathrm{M}$ & 5 \\
\hline
\end{tabular}

\section{Conclusions}

Based on flow injection analysis and spectrometric method with the addition of regents, an in-situ analyzer for nutrient determination is successfully developed. With the use of peristaltic pump, 3-port solenoid valves, sample, standards, and reagents can be selectively pumped into the fluid system, form new chemical compounds and thus can be detected. The analyzer can detect five parameters of nutrients in seawater. Detection limits are, respectively, $0.3,0.1,0.1,0.3$ and $0.2 \mu \mathrm{M}$ for nitrate, nitrite, phosphate, ammonia and silicate. With the use of wash solution and standards, baseline shift can be self-calibrated, thus the analyzer can work for long time during seawater monitoring.

\section{Acknowledgements}

This work was financially supported by the National Natural Science Foundation of China (41306103), National Key Research and Development Program of China (2016YFC0302201, 2016YFC0302204) and National Basic Research Program of China (2015CB755901).

\section{References}

[1] E. T. Steimle, E. A. Kaltenbacher, R. H. Byrne. In situ nitrite measurements using a compact spectrophotometric analysis system[J]. Marine Chemistry, 2002, 77(4): 255-262.

[2] R. D. Prien. The future of chemical in situ sensors[J]. Marine Chemistry, 2007, 107(3): 422-432.

[3] T. S. Moore, K. M. Mullaugh, R. R. Holyoke, et al. Marine chemical technology and sensors for marine waters: potentials and limits[J]. Annual Review of Marine Science, 2009, 1: 91-115.

[4] L. Adornato, A. Cardenas-Valencia, E. Kaltenbacher, et al. In situ nutrient sensors for ocean observing systems[C]//Proceedings of the Oceanobs' 09: Sustained Ocean observations and Information for Society Conference. 2009, 2.

[5] J. Ma, D. Yuan, K. Lin, et al. Applications of flow techniques in seawater analysis: a review[J]. Trends in Environmental Analytical Chemistry, 2016, 10: 1-10. 